\title{
Effect of Cu Loading to Catalytic Selective CO Oxidation of $\mathrm{CuO} / \mathrm{CeO}_{2}-\mathrm{Co}_{3} \mathrm{O}_{4}$
}

\author{
P. Aunbamrung, A. Wongkaew \\ Department of Chemical Engineering, Faculty of Engineering, Burapha University, Chonburi, Thailand \\ Email: akkarat@buu.ac.th
}

Received May, 2013

\begin{abstract}
This work studied $\mathrm{CuO} / \mathrm{CeO}_{2}-\mathrm{Co}_{3} \mathrm{O}_{4}$ with wt $\%$ Ce:Co ratio 95:5 for selective $\mathrm{CO}$ oxidation with effect of wt $\% \mathrm{Cu}$ loading. The catalysts were prepared by co-precipitation. Characterizations of catalysts were carried out by XRD and BET techniques. The results showed a good dispersion of $\mathrm{CuO}$ for $5 \mathrm{wt} \% \mathrm{Cu}$ loading catalysts and showed high specific surface area of catalyst. For selective $\mathrm{CO}$ oxidation, both $5 \mathrm{CuO}$ and $30 \mathrm{CuO}$ catalysts could remove completely $\mathrm{CO}$ in the presence of excess hydrogen at $423 \mathrm{~K}$ and $20 \mathrm{CuO}$ could eliminate $\mathrm{CO}$ completely at $443 \mathrm{~K}$. Moreover, considering the selectivity to $\mathrm{CO}$ oxidation, the $5 \mathrm{CuO}$ catalyst has shown the highest selectivity of $85 \%$ while the $30 \mathrm{CuO}$ catalyst obtains the selectivity of $65 \%$ at the reaction temperature of $423 \mathrm{~K}$.
\end{abstract}

Keywords: Selective $\mathrm{CO}$ Oxidation; $\mathrm{CuO} / \mathrm{CeO}_{2}-\mathrm{Co}_{3} \mathrm{O}_{4} ; \mathrm{Cu}$ Loading; Ce:Co Ratio; Co-precipitation

\section{Introduction}

Proton-exchange membrane fuel cell (PEMFC) has interest with automotive and residential application because of low operating temperature, high power density and rapid start up. Hydrogen is an ideal fuel for PEMFC. In many practical cases hydrogen can be produced by steam reforming, following by water gas shift reaction [1]. The presence of $1 \mathrm{vol} \% \mathrm{CO}$ in hydrogen steam gas poisons to Pt-anode of PEMFC [2]. Among the different methods for removal $\mathrm{CO}$, selective $\mathrm{CO}$ oxidation reaction is the preferred methods because this method used oxygen for $\mathrm{CO}$ oxidation and high efficiency for remove $\mathrm{CO}$ [3]. An efficiency of catalyst for reaction must be active and selective to avoid parallel $\mathrm{H}_{2}$ oxidation.

In the recent year, the $\mathrm{CuO}-\mathrm{CeO}_{2}$ catalyst has been proposed as a promising catalyst due to its low cost and high catalytic performance when compared with gold or platinum catalysts $[4,5]$. The cobalt-based catalyst has been reported shown good activity, selectivity at low temperature and $\mathrm{H}_{2} \mathrm{O}$ resistance [6]. A large number of studies catalyst preparations, the co-precipitation method are the preferred method to high specific surface area of catalyst and high activity for $\mathrm{CO}$ oxidation [7].

In this study, The $\mathrm{CuO}-\mathrm{CeO}_{2}$ catalysts promoted with $\mathrm{Co}_{3} \mathrm{O}_{4}$ were prepared by co-precipitation with different $\mathrm{wt} \% \mathrm{Cu}$ loading and define $\mathrm{wt} \% \mathrm{Ce}$ :Co ratio 95:5. The characterizations of catalyst were carried out by BET and XRD techniques, in order to correlate catalyst properties to catalytic performance. The performances of catalysts were tested by selective $\mathrm{CO}$ oxidation.

\section{Experimental}

\subsection{Catalysts Preparation}

The catalysts $\mathrm{CuO} / \mathrm{CeO}_{2}-\mathrm{Co}_{3} \mathrm{O}_{4}$ with wt $\% \mathrm{Ce} / \mathrm{Co}$ ratio of 95:5 were prepared by co-precipitation. Aqueous solutions of $\mathrm{Cu}\left(\mathrm{NO}_{3}\right)_{2} \cdot 3 \mathrm{H}_{2} \mathrm{O}, \mathrm{Ce}\left(\mathrm{NO}_{3}\right)_{3} \cdot 6 \mathrm{H}_{2} \mathrm{O}$ and $\mathrm{Co}\left(\mathrm{NO}_{3}\right)_{2} \cdot 6 \mathrm{H}_{2} \mathrm{O}$ were mixed. Aqueous $\mathrm{Na}_{2} \mathrm{O}_{3} 0.1 \mathrm{M}$ used as a precipitating agent was added drop-wise until a $\mathrm{pH}$ of 9 was attained. The resulting precipitate was aged at room temperature for $2 \mathrm{~h}$, then filtered, washed several times with deionize water and dried at $110^{\circ} \mathrm{C}$ overnight. The obtained samples were calcined at $500^{\circ} \mathrm{C}$ for $5 \mathrm{~h}$. The prepared catalysts were denoted as $\mathrm{XCuO}$. The $\mathrm{X}$ shows the $\mathrm{wt} \% \mathrm{Cu}$ loading

\subsection{Catalyst Characterization}

All catalyst powders were characterized for their surface area, average pore diameter and average crystal-liter sizes. Specific surface area $\left(\mathrm{S}_{\mathrm{BET}}\right)$ of catalysts was determined with adsorption-desorption isotherms of $\mathrm{N}_{2}$ at 77 $\mathrm{K}$ using Autosorption-1C from Quantachrome. Prior to $\mathrm{N}_{2}$-physical adsorption measurement, catalysts were degassed under N2 gas purged at $473 \mathrm{~K}$ for $12 \mathrm{~h}$. The adsorption isotherms were tested at $10-5<<1.0$. Using the nitrogen adsorption isotherm, BET equation was used for calculation of specific surface area using values between 0.05 and 0.30 . X-ray diffraction measurement was made 
using a Bruker AXS model D 8 Discover equipped with a $\mathrm{Cu} \mathrm{K} \alpha$ radiation $(40 \mathrm{kV}, 40 \mathrm{~mA})$ with a nickel filter. Dif- fraction intensity was measured in the 2 theta ranges between $20^{\circ}$ and $80^{\circ}$, with a step of $0.02^{\circ}$ for $8 \mathrm{~s}$ per point. The mean crystallite sizes of oxides were determined from the X-ray line broadening measurements, using the Scherrer equation.

\subsection{Catalytic Performance}

The selective $\mathrm{CO}$ oxidation in the $\mathrm{H}_{2}$-rich gasses was carried out in a quartz reactor inserted in a vertical furnace. The reaction mixture consisted of $1 \% \mathrm{CO}, 1 \%$ $\mathrm{O}_{2}$ and $50 \% \mathrm{H}_{2}$ (volume fraction) with $\mathrm{He}$ as a balance gas. The flow rate of gas mixture was $40 \mathrm{~cm}^{3} \cdot \mathrm{min}^{-1}$, equivalent to space velocity $75,000 \mathrm{~cm}^{3} \cdot \mathrm{gcat}^{-1} \mathrm{~h}^{-1}$. The catalyst bed temperature was measured by means of a thermocouple inserted in the furnace. Product and reactant analyses were conducted by a GC-3600CX gas chromatograph. The molecular sieve was used to separate $\mathrm{CO}, \mathrm{O}_{2}$ and $\mathrm{CO}_{2}$. Water was trapped before the gases entering the $\mathrm{GC}$.

The CO conversion and selectivity for $\mathrm{CO}$ oxidation were calculated from the concentration of $\mathrm{CO}$ and $\mathrm{O}_{2}$ at inlet and outlet of the reactor as shown in equation (1) and (2).

$$
\mathrm{CO} \text { conversion }=\frac{\mathrm{CO}_{\text {inlet }}-\mathrm{CO}_{\text {outlet }}}{\mathrm{CO}_{\text {outlet }}} \times 100 \%
$$

$$
\text { selectivity }=\frac{\mathrm{CO}_{\text {inlet }}-\mathrm{CO}_{\text {outlet }}}{2 \times\left(\mathrm{O}_{2 \text { inlet }}-\mathrm{O}_{2 \text { outlet }}\right)} \times 100 \%
$$

\section{Results and Discussion}

\subsection{Catalyst Characterization}

The powder $\mathrm{X}$-ray diffraction was applied to investigate the structure of the $\mathrm{CuO} / \mathrm{CeO}_{2}-\mathrm{Co}_{3} \mathrm{O}_{4}$ catalysts. Figure 1 shows the XRD patterns of the sample. All samples shown the presence of $\mathrm{CeO}_{2}$ in the fluorite-type cubic crystal structure, with the diffraction peak at $2 \theta$ of $28.55^{\circ}$, $33.08^{\circ}, 47.48^{\circ}, 56.34^{\circ}$ and $76.70^{\circ}$. Strong two diffraction peaks of $\mathrm{CuO}$ are exhibited the high crystalline structure of monoclinic tenorite-phase $\mathrm{CuO}$ in the $20 \mathrm{CuO}, 30 \mathrm{CuO}$ and $40 \mathrm{CuO}$ at $2 \theta=35.46^{\circ}$ and $38.73^{\circ}$. For $10 \mathrm{CuO}$, the diffraction peaks of $\mathrm{CuO}$ are weak in the XRD patterns, suggesting that $\mathrm{CuO}$ is highly dispersed on the fluorite $\mathrm{CeO}_{2}$ support. Accordingly, no $\mathrm{CuO}$ peaks are observed for $5 \mathrm{CuO}$, probably due to very low metal loading and its high dispersion [8]. For diffraction peaks of $\mathrm{Co}_{3} \mathrm{O}_{4}$ in all samples not recognize due to very low of $\mathrm{Co}_{3} \mathrm{O}_{4}$ promoted to catalysts. The average crystalline sizes of catalyst were calculated by Scherer's equation. The average size of $\mathrm{CeO}_{2}$ are about 7-10 nm and $\mathrm{CuO}$ are more than $10 \mathrm{~nm}$ (Table 1.)

The isotherm of the catalysts at different $w t \% \mathrm{CU}$ loading reveals a typical type IV sorption behavior, representing the predominant mesoporous structure characteristic as shown in Figure 2.

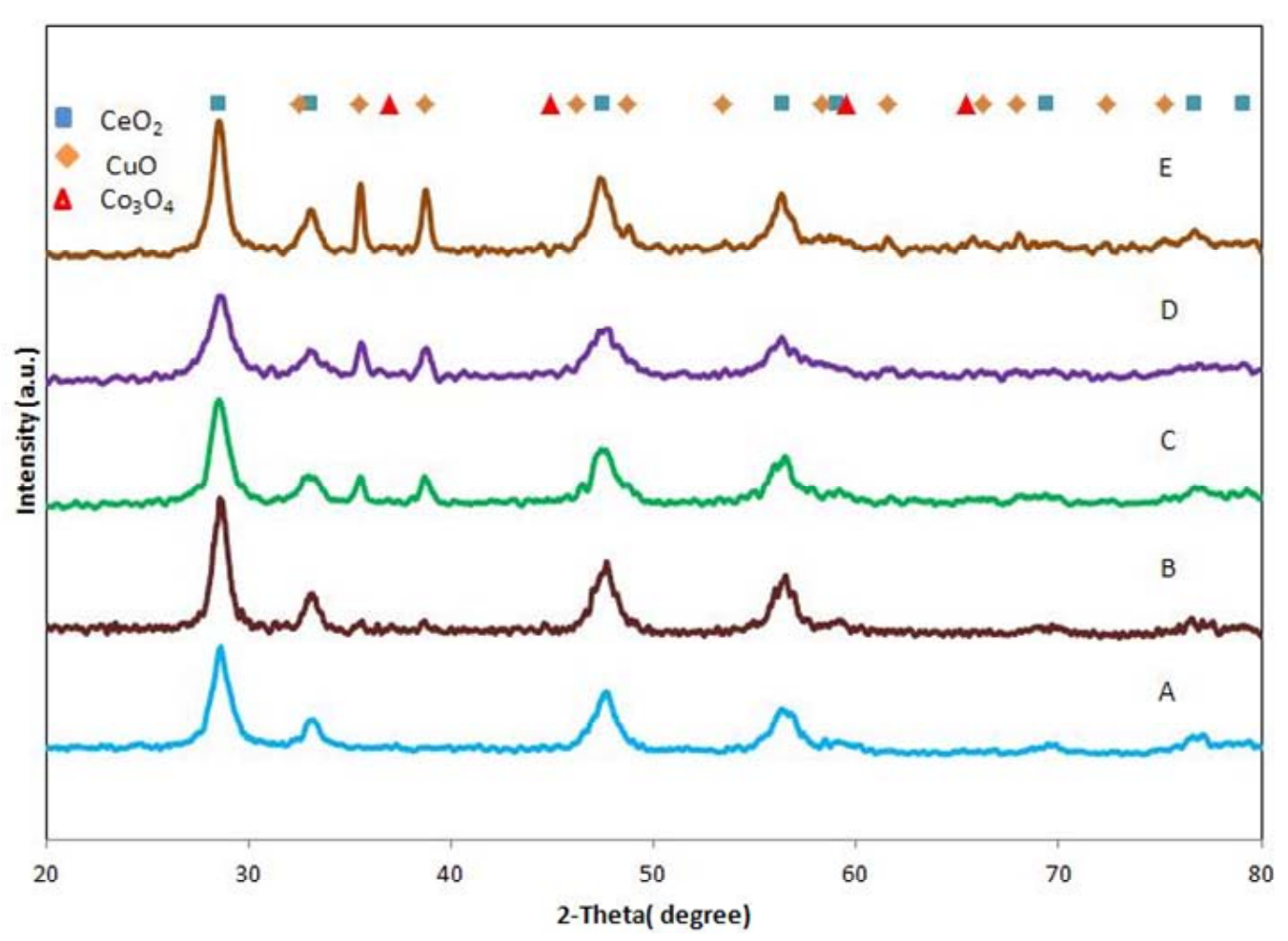

Figure 1. XRD patterns of the catalysts (A) 5CuO; (B) 10CuO; (C) 20CuO; (D) 30CuO; (E) 40CuO. 
Table 1. The properties of $\mathrm{CuO} / \mathrm{CeO}_{2}-\mathrm{Co}_{3} \mathrm{O}_{4}$ catalysts.

\begin{tabular}{|c|c|c|c|c|c|c|}
\hline \multirow{2}{*}{ Catalysts } & \multicolumn{3}{|c|}{ Crystalline size } & \multirow{2}{*}{$\begin{array}{c}\mathrm{S}_{\mathrm{BET}} \\
\left(\mathrm{m}^{2} \cdot \mathrm{g}^{-1}\right)\end{array}$} & \multirow{2}{*}{$\begin{array}{c}\mathrm{d}_{\text {pore }} \\
(\mathrm{nm})\end{array}$} & \multirow{2}{*}{ Phase detected } \\
\hline & $\mathrm{d}_{\mathrm{CuO}}(\mathrm{nm})$ & $\mathrm{d}_{\mathrm{CeO} 2}(\mathrm{~nm})$ & $\mathrm{d}_{\mathrm{CO3O4}}(\mathrm{nm})$ & & & \\
\hline $5 \mathrm{CuO}$ & - & 7.9 & - & 105.4 & 6.9 & $\mathrm{CeO}_{2} / \mathrm{Cubic}$ \\
\hline $10 \mathrm{CuO}$ & - & 9.5 & - & 73.3 & 8.4 & $\mathrm{CeO}_{2} / \mathrm{Cubic}$ \\
\hline $20 \mathrm{CuO}$ & 14.7 & 7.9 & - & 121.2 & 8.7 & $\mathrm{CuO} /$ monoclinic, $\mathrm{CeO}_{2} / \mathrm{Cubic}$ \\
\hline $30 \mathrm{CuO}$ & 13.7 & 7.1 & - & 136.5 & 8.8 & $\mathrm{CuO} /$ monoclinic, $\mathrm{CeO}_{2} / \mathrm{Cubic}$ \\
\hline $40 \mathrm{CuO}$ & 23.5 & 10.2 & - & 31.3 & 21.0 & $\mathrm{CuO} /$ monoclinic, $\mathrm{CeO}_{2} / \mathrm{Cubic}$ \\
\hline
\end{tabular}

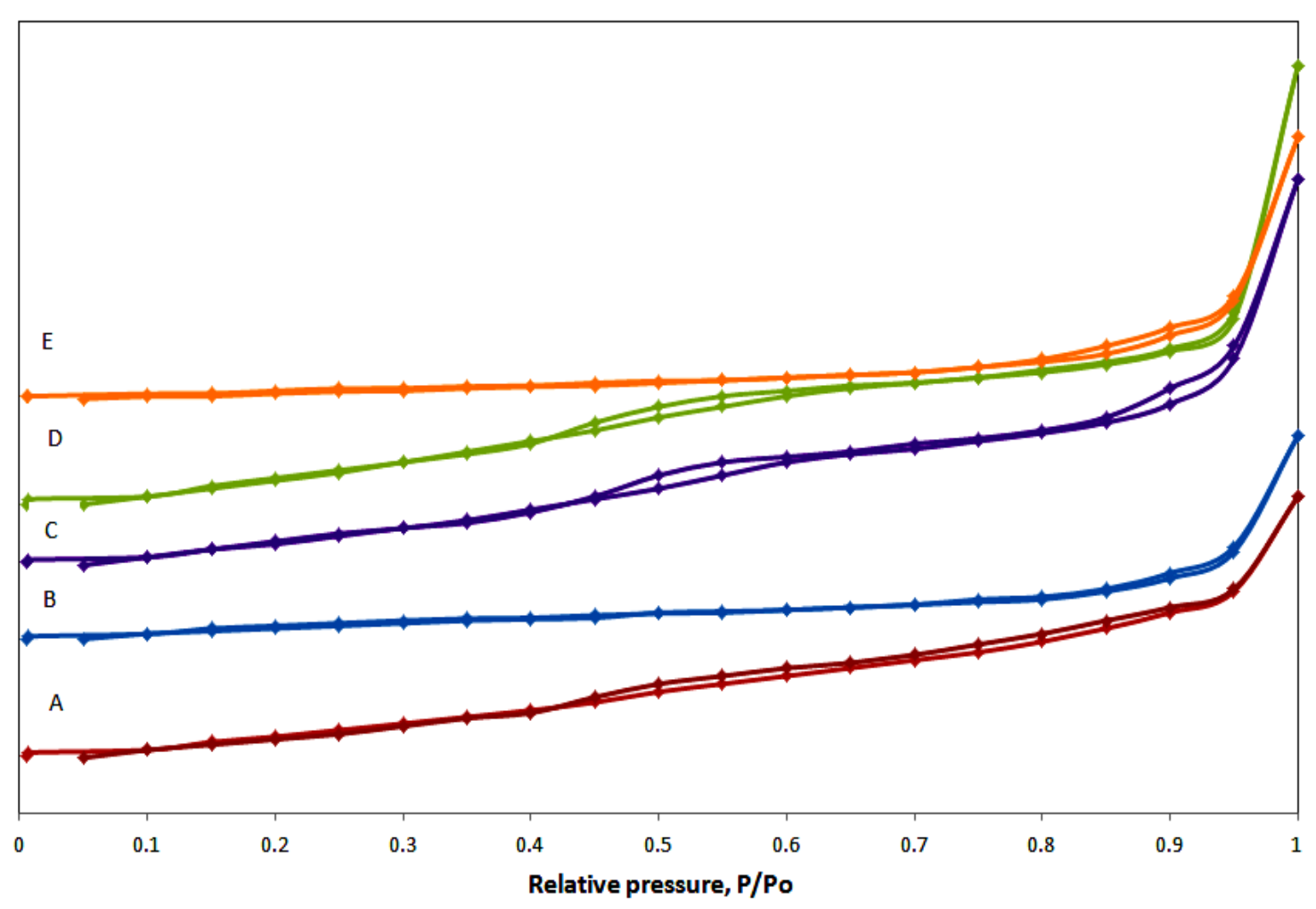

Figure 2. Isoterms of the catalysts (A) 5CuO; (B) 10CuO; (C) 20CuO; (D) 30CuO; (E) 40CuO.

The volume of $\mathrm{N}_{2}$ adsorbed on the catalyst surface decreases with increasing $\mathrm{CuO}$ up to $40 \mathrm{wt} \%$, which indicates that coverage of $\mathrm{CuO}$ decreases the specific surface area of the sample [9].The $\mathrm{S}_{\mathrm{BET}}$ of $\mathrm{CuO} / \mathrm{CeO}_{2}$ $-\mathrm{Co}_{3} \mathrm{O}_{4}$ catalysts were calculated by Brunauer EmmettTeller (BET) method using data from $\mathrm{N}_{2}$ adsorptiondesorption isotherm with in between 0.05-0.35 and the results are reported in Table $\mathbf{1}$.

High surface area is usually helpful to enhance catalytic activity due to more surface active centers exposed to reactants. The sample prepared by co-precipitation exhibits the highest specific surface area all the samples. The $30 \mathrm{CuO}$ catalyst with the highest BET surface area displays the best CO PROX performance, indicating that the BET surface area is possibly one of the important influencing factors on the catalytic performance of $\mathrm{CuO} /$ $\mathrm{CeO}_{2}-\mathrm{Co}_{3} \mathrm{O}_{4}$ catalysts. Generally, high BET surface area is favorable to the dispersion of $\mathrm{Cu}$ species, enhancing the interaction between ceria and $\mathrm{Cu}$ species. [10]

\subsection{Catalytic Performance}

The catalytic performance of the catalysts was accomplished in the CO-PROX reaction by using a synthetic gas $\left(1 \% \mathrm{CO}, 1 \% \mathrm{O}_{2}, 50 \% \mathrm{H}_{2}\right.$, He balance). Figure 3, obviously indicates that the catalyst presents higher catalytic activity at lower temperature in the presence of excess hydrogen. The CO conversions of catalysts are the function of temperature. $\mathrm{CO}$ conversion increases with an increase in reaction temperature and further increasing in reaction temperature decreases $\mathrm{CO}$ conversions. The maximum $\mathrm{CO}$ conversion for $5 \mathrm{CuO}$ is $100.0 \%$ at the reaction temperature in the range between $423-443 \mathrm{~K}, 10 \% \mathrm{CuO}$ is 98.1 at $463 \mathrm{~K}, 20 \mathrm{CuO}$ is $100.0 \%$ at $443 \mathrm{~K}, 30 \mathrm{CuO}$ is $100 \%$ at the reaction temperature in the range between 
$423-443 \mathrm{~K}$ and $40 \mathrm{CuO}$ is $98.5 \%$ at $463 \mathrm{~K}$. At the increase temperature, $\mathrm{CO}$ conversion decreases. This may be due to high competition between $\mathrm{H}_{2}$ oxidation and $\mathrm{CO}$ oxidation or reverse water gas shift reaction [11].

The selectivity can be seen in Figure 4, the selectivity for CO oxidation is $100 \%$ over the catalysts at reaction temperature lower than $403 \mathrm{~K}$ for $5 \mathrm{CuO}, 20 \mathrm{CuO}$ and $30 \mathrm{CuO}$ and lower than $423 \mathrm{~K}$ for $10 \mathrm{CuO}$ and $40 \mathrm{CuO}$. It means that $\mathrm{H}_{2}$ oxidation does not happen until this temperature. At the increase temperature the selectivity tends to decrease, indicating that the $\mathrm{H}_{2}$ oxidation occurs over the catalysts. It can be suggested that the adsorption and catalytic take place at low temperature. When the temperature increases $\mathrm{H}_{2}$ molecules can be adsorbed and reaction[8]. In addition, a decrease in the amount of $\mathrm{CeO}_{2}$ in catalyst may result in a decrease in selectivity at high temperature due to the reduction of oxygen storage [12]. The selectivity of catalysts at the max $\mathrm{CO}$ conversion is $85 \%$ for $5 \mathrm{CuO}, 50 \%$ for $10 \mathrm{CuO}, 70 \%$ for $20 \mathrm{CuO}, 65 \%$ for $30 \mathrm{CuO}$ and $52 \%$ for $40 \mathrm{CuO}$ catalysts.

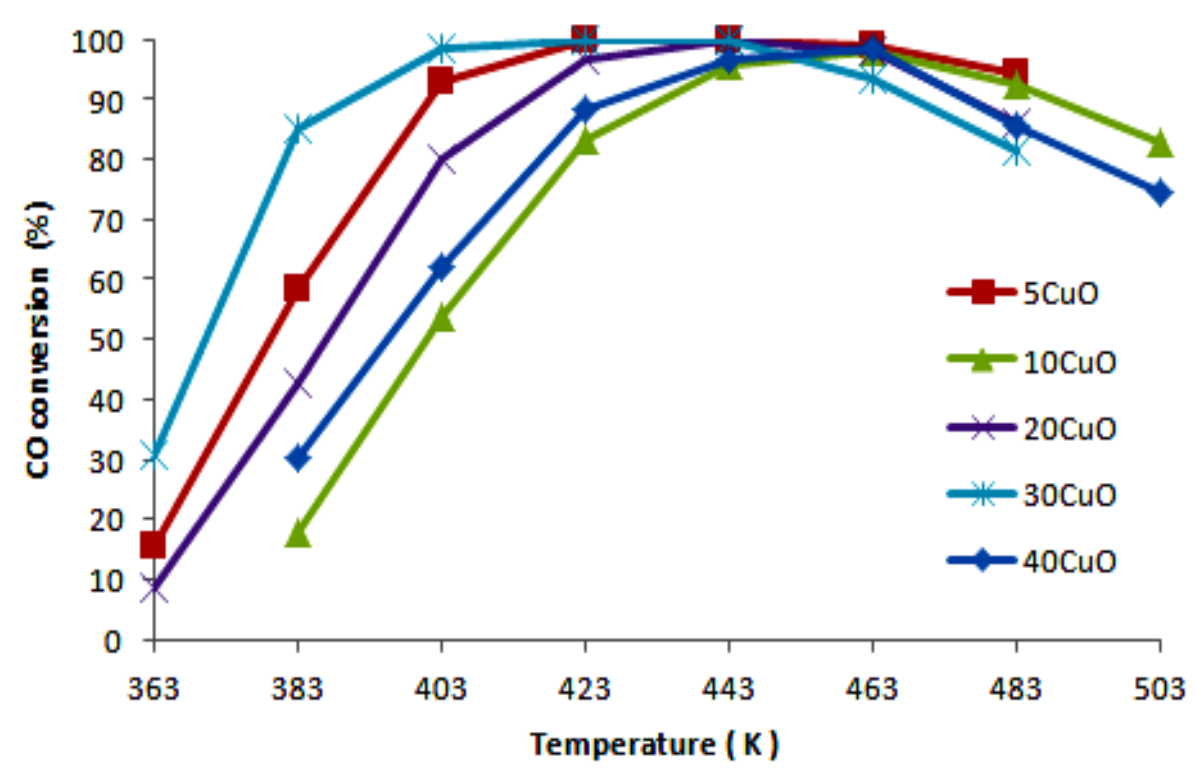

Figure 3. The $\mathrm{CO}$ conversion of catalysts as a function of temperature.

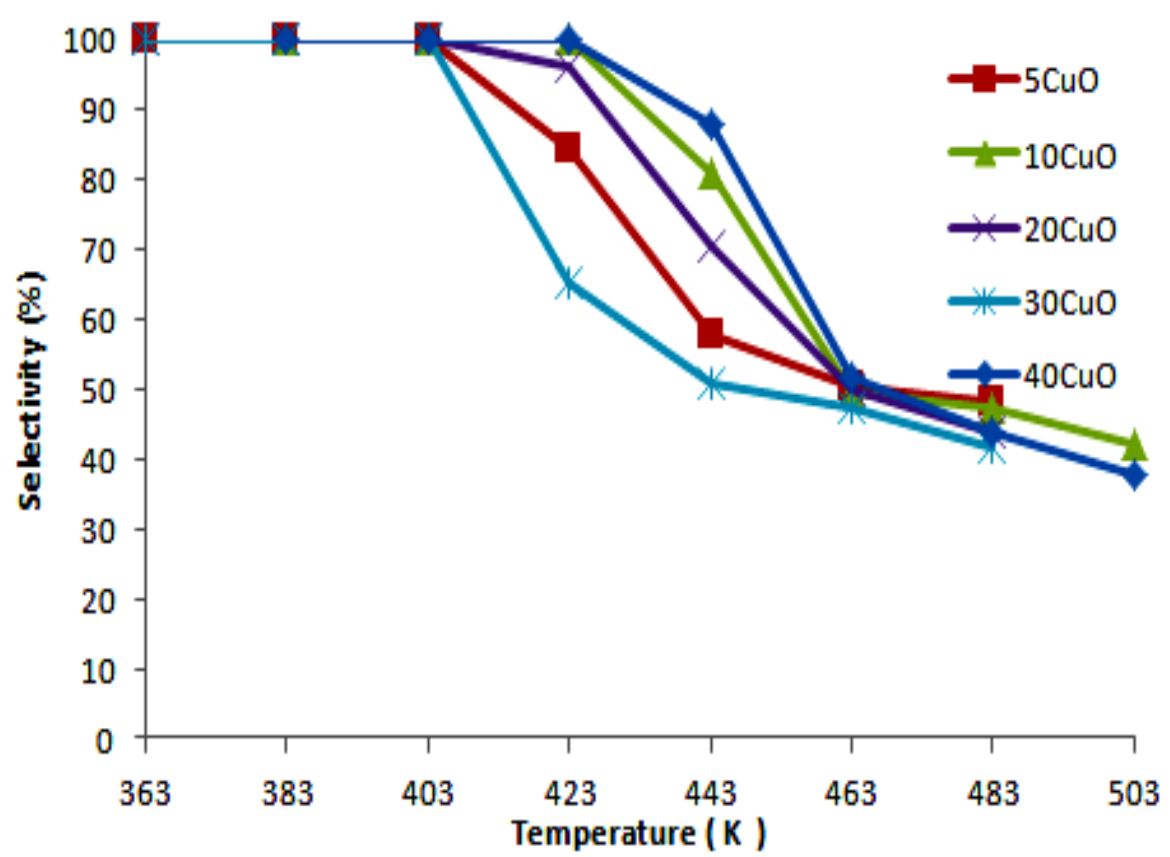

Figure 4.The selectivity of catalysts as a function of temperature. 
It can also be concluded that, the $\mathrm{wt} \% \mathrm{Cu}$ loading has an effect on selective $\mathrm{CO}$ oxidation. Adding more $\mathrm{CuO}$ increases activity and $\mathrm{CO}$ removal at low temperature. For $\mathrm{CO}$ oxidation, the catalysts activity in presence of excess hydrogen is as follows, $30 \mathrm{CuO}>20 \mathrm{CuO}>40 \mathrm{CuO}$ $>10 \mathrm{CuO}$. In contrast, when comparing the selectivity at the maximum $\mathrm{CO}$ conversion, the activity of catalyst is as follows; $20 \mathrm{CuO}>30 \mathrm{CuO}>40 \mathrm{CuO}>10 \mathrm{CuO}$.

The $5 \mathrm{CuO}$ catalyst show the highest activity with $100 \%$ $\mathrm{CO}$ conversion and $85 \%$ selectivity for removal $\mathrm{CO}$ in $\mathrm{H}_{2}$-rich gas. A good dispersion of $\mathrm{CuO}$ in catalyst made to easily adsorb $\mathrm{CO}$ and activity with $\mathrm{O}_{2}$ rapidly. Including the appropriate amount of cobalt oxide to promote efficient catalysis of $\mathrm{CuO}$ and high specific surface area.

\section{Conclusions}

The $\mathrm{CuO} / \mathrm{CeO}_{2}-\mathrm{Co}_{3} \mathrm{O}_{4}$ catalysts were prepared by coprecipitation method and characterized by the XRD and BET techniques. XRD measurements show that the catalysts are composed of monoclinic $\mathrm{CuO}$ and cubic fluorite $\mathrm{CeO}_{2}$. BET shows the large surface area and small average pore size diameter. The performance of catalyst suggest the $5 \mathrm{CuO}$ shows the best activity at low temperature and shows high selective $\mathrm{CO}$ oxidation when the $\mathrm{CO}$ conversion reach to $100 \%$. The performance of catalysts verifies that complete in the CO-PROX system.

\section{Acknowledgements}

This research was supported by Burapha University (NRCT 2555) under the contract \# 48/2555.

\section{REFERENCES}

[1] O. Bicakova and P. Straka, "Production of Hydrogen from Renewable Resource and its Effectiveness," International Journal of Hydrogen Energy, Vol. 33, 2008, pp. 1335-1344.

[2] Z. Nada and L. Xianguo, "Transient of Carbon Monoxide Poisoning and Oxygen Bleeding in a PEM Fuel Cell Anode Catalyst Layer," International Journal of Hydrogen Energy, Vol. 33, 2008, pp. 1335-1344.

[3] A. Mishra and R. Prasad, "A Review on Preferential Oxidation of Carbon Monoxide in Hydrogen Rich Gas," Bulletin of Chemical Reaction Engineering \& Catalysis, Vol. 6, No. 1, 2011, pp. 1-14.
[4] G. Avgouropoulos, T. Ioannides, C. Papadopoulou, J. Batista, S. Hocevar and H. K. Matralis, "A Comparative Study of $\mathrm{Pt} / \gamma-\mathrm{Al}_{2} \mathrm{O}_{3}, \mathrm{Au} / \alpha-\mathrm{Fe}_{2} \mathrm{O}_{3}$ and $\mathrm{CuO}-\mathrm{CeO}_{2}$ Catalysts for the Selective Oxidation of Carbon Monoxide in Excess Hydrogen," Catalysis Today, Vol. 75, 2002, pp. 157-167. doi:10.1016/S0920-5861(02)00058-5

[5] S. Salvatore, C. Carmelo, P. M. Riccobenea, P. Giacomo and P. Alessandro, "Selective Oxidation of $\mathrm{CO}$ in $\mathrm{H}_{2}$-rich Stream over $\mathrm{Au} / \mathrm{CeO}_{2}$ and $\mathrm{Cu} / \mathrm{CeO}_{2}$ Catalysts: An Insight on the Effect of Preparationmethod and Catalyst Pretreatment," Applied Catalysis A: General, Vol. 417418, 2012, pp. 66-75.

[6] M. Kang, M. W. song and C. H. Lee, "Catalytic Carbon Monoxide Oxidation over $\mathrm{CoO}_{\mathrm{x}} / \mathrm{CeO}_{2}$ Composite Catalysts," Applied Catalysis A: General, Vol. 255, 2003, pp. 143-156. doi:10.1016/S0926-860X(03)00324-7

[7] Z. Liu, R. Zhou and X. Zheng, "Influence of Preparation Methods on $\mathrm{CuO}-\mathrm{CeO}_{2}$ Catalysts in the Preferential Oxidation of $\mathrm{CO}$ in Excess Hydrogen," Journal of National Gas Chemistry, Vol. 17, 2008, pp. 125-129.

[8] J. L. Ayastuy, E. Fernandez-Puertas, M. P. Gonzalez-Marcos and M. A. Guitierrez-Ortiz, "Transition metal Promoters in $\mathrm{CuO} / \mathrm{CeO}_{2}$ Catalysts for $\mathrm{CO}$ Removal from Hydrogenstreams," International Journal of Hydrogen Energy, Vol. 37, 2012, pp. 7385-7397. doi:10.1016/i.ijhydene.2012.02.007

[9] S. Christopher, H. Nair and D. Chelsey, "Study of Active Sites and Mechanism Responsible for Highly Selective $\mathrm{CO}$ Oxidation in $\mathrm{H}_{2}$ Rich Atmospheres on a Mixed $\mathrm{Cu}$ and Ce Oxide Catalyst," Journal of Catalysis, Vol. 266, 2009, pp. 308-319. doi:10.1016/j.jcat.2009.06.021

[10] M. Meng, Y. Liu, W. L. Z.Sun, L. Zhang and X. Wang, "Synthesis of Highly-dispersed $\mathrm{CuO}-\mathrm{CeO}_{2}$ Catalyst Through a Chemisorption-hydrolysis Route for CO Preferential Oxidation in $\mathrm{H}_{2}$-rich Stream," International Journal of Hydrogen Energy, Vol. 37, 2012, pp. 14133-14142. doi:10.1016/j.ijhydene.2012.07.075

[11] J. W. Park, J. H. Joeng, W. L. Yoon, C. S. Kim, D. K. Lee, Y. K. park and Y. W. Rhee, "Selective Oxidation of $\mathrm{CO}$ in Hydrogen-rich Stream over Cu-Ce Catalyst Promoted with Transition Metal," International Journal of Hydrogen Energy, Vol. 30, 2005, pp. 209-220. doi:10.1016/j.ijhydene.2004.04.016

[12] S. Chang, M. Li, Q. Hua, L. Zhang, Y. Ma, B. Ye and W. Huang, "Shape-dependent Interplay between Oxygen Vacancies and $\mathrm{Ag}-\mathrm{CeO}_{2}$ Interaction in $\mathrm{Ag} / \mathrm{CeO}_{2}$ Catalyst $\mathrm{s}$ and Their Influence on the Catalytic Activity," Journal of Catalysis, Vol. 293, Vol. 30, 2012, pp. 195-200. 